\title{
ANALYSES ON LEGAL SYSTEMATIC ARRANGEMENT AND POLICE STANDARD OPERATING PROCEDURES
}

Erdenebaatar D.

Police School, Law Enforcement University, Mongolia corresponding author,e-mail:d.erdenebaatar@yahoo.com

\begin{abstract}
Like any country carries out both foreign and domestic policy management, similarly administration also carries out internal and external operations and manages them with legal norms. From this, the internal administrative operation of the police organization and its legal management is directed towards ensuring the implementation of the law and improving operation results of its personnel and organizations. As the legal act systemization is also directed towards result improvement, hence I propose that it is of importance and demand to study the interconnection between them and utilization of it in practice.

The purpose of this study is to show the results and differences from implementing legal techniques in the legal sector and establishment of legislative institutions, viewing legal act systemization technique as the theoretic foundation for systematic creation of the legal norm acts of the police organization's internal operation rather than the narrow view of it as only legislation.
\end{abstract}

Keywords: law; systemization; codification; by-law; legal techniques; internal rule;

\section{INTRODUCTION}

As of 2008, there were approximately 450 legal acts that were approved and enforced by the chiefs of the central police organization and other organizations of administrative government, which had negative impact on the daily operation of police organizations due to the legal mistakes, legal gaps, overlaps, conflicting content, insufficient implementation mechanisms, unclear sources and even doubt of whether some of them were active legislative acts or not.

In addition to this, there are 166 active norms of approximately 90 laws that authorize and bestow responsibility to police personnel and organizations without involving laws on overseeing and solving felony criminal and violation cases. Presenting difficulties in accurate implementation of these norms due to the authorized organization units or personnel are not being appointed and the lack of developed management rules, guides and regulations.

The inaccurate and incomplete condition of the legal environment has direct negative impact on the operation of the police organizations, especially giving rise to the inappropriate use of law by police personnel and victimization of the citizen due to it, even touching on the legal interests of the police personnel himself.

Also, the outstanding issues that need immediate attention such as passing of the legal acts at different times by different authorities, unclear condition of whether there have been additions and edits to these norms, insufficient information, the inability of the 
outdated rules and regulations to manage newly created norms have created the demand to systematize the legal acts that are directed towards management of the internal operation of the police organization.

Due to the conditions stated above and in order to facilitate unhampered operation of the police organization within framework of the law, Police Standard Operating Procedures (PSOPs, 2011) has been passed and is in its 6th year of trials. In order to improve and develop police organization operation rules and its system, there is a demand to resolve hindrances through to defining ideology, theory and interpreting core concepts.

The uniqueness of this study rests in the fact that this is the first comprehensive study of legal act systematization that manages police organization operation with deliberate attention to its theory and practice.

Literature review: The topic of this study raises number of interdependent issues at the legal crossing points of administrative law, police law, comparative law, theory of law, history of law, philosophy of law, criminology, and criminalistics. Number of foreign and domestic scientists have studied the police operation rules as the source of police law within the conceptual framework of government/administrative elements, concept, the progress of creation and development, legal technique and systematization, codification, structure and published their finding in their works.

Also, labour law researcher defined that within ethical framework of labour the duties of the employees and the employer, internal labour regulation and disciplinary measures are compound sum of legal norms.

During the 1960's, the foundational period of independent development of legislative science in our country, the published work "On some issues of classifying and organizing acts of establishing norms of authority in People's Republic of Mongolia" by Jamiyan (1967) became the first scientific work to analyse the classification, systematization, concepts, types of systematization, indexation of acts and methods of organizing it such as, codification, incorporation, consolidation, classification, creation of inquiry apparatus and tools, project development techniques from theory and practice.

In addition to this, Amarkhuu (2008) and Lundeejantsan (2016) warned in their work that the legal technique and within it the formula of law systematization, legislative act systematization concepts, type, methods and history of systematization starting from 1950's is severely outdated in the present conditions.

Russian scientist wrote on the duties of the police organizations within the law enforcement structure and legal management of its operation, whilst studying and defining the government services provided by interior organization towards the population, developing a list of services provided by the state interior organization to civilians, and developing rules and regulations for those services.

Many foreign scientists focus on police organization and its operation. Police administration: structures, process, and behavior by Charles R Swanson (2011). Police administration: A Leadership Approach by Ortmeier (2010) could be mentioned on administrative operation, theoretic foundation of operation management of police organizations. Policies, procedures and standards: an approach for implementation, information management and Computer Security by Barry Moule and Lina Giavara (1995). Whilst Nick Kapp wrote the Developing SOP (2013).

Looking from present results of police studies in Mongolia, in the last 50 years or from 1970-2015 a total of 242 scientific reports and works have been submitted, although the majority of which or 98 works are on content of "Improving/perfecting police organization law, systematization", they still viewed the term "legislation" from wide angle of view.

Finally, based on above research, conclusion is established that: 1) To this day, 
there is no comprehensive study on legislative acts managing police organization operation and its systematization, especially its theory and practical utilization issues. 2) It draws attention that although domestic studies were carried out in 1960's on tools of legislative act systematization such as codification, incorporation, consolidation, classification, techniques on creating laws, there is long period of neglect and absence of work until the year 2016.3) There is enough research and

\section{MATERIAL AND METHODS}

Theoretical basis of the research study comprises academic studies of foreign and national professionals, resources of international and national laws, and official policies. On the other hand, methodological basis of the research study contains research reports, articles, statistics, and comparisons for practical routine, analysis, classifications, and summarizations. Moreover, research paper has done with sociological researches including surveys, literature reviews, approaches for qualitative, mathematical, and theoretical and they are used by logical.

Analyzing the implementation of police standard operational procedures is to use scientific methodologies such as conducting surveys, focusing on interviewing, observing and analyzing documents, collecting data,

\section{RESULTS AND DISCUSSION}

Standard operating procedure's historical review: In order to understand the philosophy and true nature of police organization operation rules as established legal norm and systematized legislative act, there is demand to research legal theory within which we must look into legal techniques, legal act systematization techniques.

This may be connected with the fact that within the framework of legal theory, it is not only about systematizing law, rather its systematization of all types of legal acts. In materials from foreign and domestic scientist on administrative and police legislation, legislation theory, legislation philosophy to sufficiently establish the theoretic and practical foundations. 4) From the mentioned works of foreign specialists, we could introduce the values and legal culture, new and important methodologies of countries of the world and thus make concrete steps in comparative legislation development.

mathematical and statistical methods (SPSS), evaluating the implementation of regulations, reviewing, and making general and specific conclusions.

In advance, the use of scientific hypothesis in the research obtains positive results. The hypothesis is "systematically coding and enforcing regulatory activities influence a positive impact on police operations" and attempted to prove it using the results of questionnaire by police officers.

In order to examine the hypothesis of the research, identifying the independent and dependent variables and then transfer them into quantitative assessments. After that, mathematical processing data show that a positive result as hypothesis is claimed by correct.

other words, the philosophy of systematization of legal acts is singular and independent from the type of legal act.

However, the additional act of operation rules, it comes from philosophy of "auftragstaktik" or "instructed control" (order tactics) which was proposed by the Prussian major general Gerhard von Scharnhorst after the loss of the Prussian Army to Napoleon in 1806, later implemented by Prussian field marshal Helmuth von Moltke who had worked as the army chief of staff for 30 years. 
Instructed control in military science has been explained as "principle of interconnected and chain administration, regulation that ensures justice is the foundation for control success." Thanks to 50 years of research by Austro-American philosophers Edward Deming and Peter Drucker this philosophy was introduced to other sectors of society.

Researchers refer to the concept of "auftragstaktik" as "filed or packaged". It is about providing a unified code of conduct for the unambiguous understanding of the policies, goals, strategic goals and according to which personnel can think creatively and make active decisions. In this regard, Helmuth Von Moltke (1800) concluded that "the operating procedure is the guarantee of your organization's survival, security and facilitator of the working environment." As analyst, I view the word "filed" represents the core content of legal systematization "integrating, compiling, writing, publishing".

In foreign countries the operation procedures put in place by administrative organizations is referred to in many different names such as: "Business policies and procedures", "Standard operating procedures /SOP/", "Department operating procedures /DOP/", "Regulations and procedures", "Statutory Orders and Regulations (SOR)", "Code of Practice", "Operation guidelines", "Artbeitsanweisungen", etc...

This is known in Mongolian laws as "Labor Code of Conduct" and "Policy Paper", but this legal document provides the behavioral procedures necessary for the proper conduct of personnel (Dwayne, 2008) and we can see that in the European Union and other countries, it is referred to as "Standard Operating Procedures" (SOPs). The Nobel Prize winner, Janet L. Nolen (2009), referred to use of systematized legal norm acts as the "standard operating procedures" (SOP) which defined the middle period of the 20th century.

The most important feature of the standard operating procedures is the "set" or the complex, sorted and integrated legal norm acts. To illustrate the most important feature of the systematized, the "procedures" contained in the "operating procedures" in English are "codes" and "operational procedures" in the "set of codes" indexed a set of legal acts ". In other words, in the case of the term "Operational Procedures", in terms of the legal science it has become a systematized act.

Agency internal rule, what is it for: French educator C. L. Montesquieu says, "When I go to a country I'm don't check whether their law is good or bad, rather I pay attention to the actual implementation of the law, because good laws are everywhere" (Nyamsuren, 2017). Legal effect and ability of regulatory mechanisms of legislation are dependent on implementation of law, so implementation of legislation is the core process of legal management. Therefore, implementing the law means introducing the law into real practice, and the legal norms find their intended subject purpose (Alekseev, 2004), and the non-implemented legislation is not legislation (Lazarev, 1997).

Therefore, in order to ensure the effectiveness of the law and its effect, the government administrative branch units such as the ministries and agencies issue acts to manage relations within the sector, acts in the forms of such as orders, instruction, rules and regulation. These acts are the norm acts to ensure implementation of other acts and define direction operation for particular organization or officials.

These acts in legal sciences are called local act or by-laws in English speaking countries. By the area of effect, legal norms are classified as nationwide and local, local acts is norms effective in provincial self-governing areas, government administrative organization and its framework which is called corporative norms (Nyamsuren, 2017).

Corporative norms or organizational structural acts are only within the operation and methodology of that particular organization. Kashanina (2016) defined corporative legislation as "organizations internal legislation". 
In addition, the legal norms are classified as material (application) and process (procedure norm) in which processes (procedure norms) are further classified as processes and procedural. The operational procedures of the police as the norm act on operational technology and rules falls under the procedural legislation or the organizational operation legislation.

The above mentioned technology during the middle of 1900's was combined with social sciences, where administration becomes a system that turns its own resources to service, process of which is managed legal norms can be viewed as operation procedure. In other words, police operation procedure is corporative legal act or a local act that is only effective within the police organization and personnel.

Some foreign researchers gave the following definition on police operation procedures. For example: Nancy on question "How to do it?", a norm of hand execution methodology (Campbell, 1997). David (2012) on "Who does what and when?" has given a document on how to schedule and defined operational discipline. Dwayne (2008) said the police operation procedure is detailed management document to aid towards the fulfillment of duty and responsibility.

For Isin (2012), in his work of defining demand for operation procedure, he explained it from the viewpoint of quality management, according to which the benefits of operation procedure lie in organization, ensured security, preliminary warning, technology supply and improved quality management.

Researchers agree with the following views. Harold (2001) viewed that the internal legislative norms sited in the constitution, for example the internal operation procedure must be followed by respective organization themselves. Andrew and Rodney (2014) followed Akkardian philosophy which professed government organizations must follow internal operation procedures created by themselves, if this is not the case, then that administrative act is invalid and inactive.

According to Marx Weber, importance of organization operating procedure lies in improving the operation results of organization itself, also procedures are created in order for personnel to properly utilize authority in various conditions (Daniel, 2010). Knowledge of such administrative operation and technique is of great importance.

Legal systematization and its type: There are many objective and subjective reasons for legal act systematization. These reasons are directed towards improving quality and results of operation. In administrative law the duty of administrative organization is to carry out effective operation of itself. The foundation of corporative or the organizational internal legislation philosophy is based on the following principles: Firstly, utilitarian or organizational decisions must be of benefit to the people. Secondly, respect of human rights, freedom, independent judicial system and justice, voice of the people, privacy, and freedom of religion, adherence to tradition and assurance of labor safety. Third, proper decisions based on equality before justice, in sentencing, reward and benefits, as well as absence of discrimination and appropriate management to the given situation (Kashanina, 2016).

The core purpose of the legal structure is to administer the behavior people through rules and regulations. In order to effectively administer people's behavior, the legal structure must be organized on proper moral principles. The founders of the new legal positivism philosophy Hans Kelsen (1992) and Herbert Lionel Adolphus Hart (1961) viewed that legislation is adapted logical structure of norms where government personnel must carry their operation in adherence to their own behavior procedures.

In order to improve the operation of government organizations, especially police organization, their authority and operation must be defined and based on the law/ legislation, in addition to the methodology of operation must be defined by legislative acts and techniques. 
Technique itself is tool to facilitate demand; legal technique is method and tool for creating, organizing, practicing, and interpreting legislative norm projects. The purpose of the systematization of legal acts is to perfect and eliminate internal conflicts and gaps within legal norms.

Researchers agree with Kartashov and Kashanina on that: "The systematization of legal documents is the foundation of effective operation of all organizations." From this, operation of organizations must have legal acts and various documents geared towards managing internal operation. All of this is the foundation of effective operation of organizations.

To compare the systematization methodology of legal acts, the purpose of systematization methods is one and the same. Incorporation method organizes and classifies legal acts without editing and interfering with its management content. Codification method creates, regulates, classifies and integrates renewed legal norms (codex, rules and regulation etc...).

However, the difference of the consolidation method from the methods stated above is that does not change the management content, has list of terminology, unified professional linguistic narration, integrates and classifies similar legal norms, creates classified and indexed foundation of legal act registration. The similarities of these methods are classification of legal acts and norms.

From these, the codification is preferred for the close combination of regulation and renewal of legal norms. From international analysis, European Union utilizes codification in full context and prefers this methodology for making decisions, legal acts, regulation and instruction.

However, France that falls under RomanGermanic legal family group views codification as overly wide and inhibited (Pilipenko, 2001). Codification as inhibited method and within framework of content is the process of creating classified law, as wide concept is unified legal document that eliminates conflict between legal acts without changing content, also discharging outdated articles and provision through method integration.

Codification is the method that organizes and creates unified legal norm acts through complete redevelopment of legal norm act contents.

Terms Codification and Codex are viewed as a singular concept within the legal norms (Kabrik, 2007). Codex is codified legal act and is not classified law but a legal norm act. Codex and codification in wide framework is a codified statement of integrated legal norms.

According to Zimmerman (2014), codification is wide scale and comprehensive operation with indivisible norms that is created and becomes legitimate with the participation of the government. There are three characteristics required for comprehensively integrating legal acts: First, codification is interdependent norms that creates center for source structure through approving new legal acts. Second, codification is accurate and internally interlinked concept that creates legislation and eliminates numerous unnecessary models. Third, codification method operates and codifies by legal sector and type of legal acts (Zimmermann, 2014). This characteristic serves as foundation for creating object of systematization of legal act.

From research, the systematization technique of police organization operation has number of general and special principles that depend on various conditions of organizational operation. For developing internal legal norms acts of organization the following principles must be adhered to. For instance, norm presumption principle, internal ranking principle on legal acts, principle of mandatory compliance to legal responsibility, principle of providing balance, principle of not giving responsibility to $3 \mathrm{rd}$ parties, principle of not violating the rights of others, principle of not undermining legal status, principle of employee participation in organizational restructuring, principle correcting own mistakes. 
Thus, it is mandatory to effectively develop internal legal norms acts without any mistakes. Because the objective, coverage and level of systematization technique of legal acts depends and varies on the duties, goals and number of employees of the organization it is impossible to approve or disapprove on systematization technique proposed by researchers.

As for our country the characteristic of the public service pre-administration reform was that it had no legislations and the legal status of the public service officials were no different to officials working in other organizations and public institutions. Legal status of any workers during the People's Republic of Mongolia was regulated by the Law on labor. From 1930 to 2004 a right to introduce and enforce administrative operating procedure of a police organizations stating "every organization shall follow operating procedure in order to arrange works (Baasan, 2003)" were given by the law on Labor assessors and law on labor. The first regulation apart the labor law on executive power agencies and administrative operating procedure were made as the Law on legal status of the government agency was passed in 2004.

Even though it legalized the operating procedure must have things of agency works and enabled to reflect other things stated in the law, the terminology "labor" the same as stated in the Law on labor is seen as an inappropriate terminology for state administrative organizations who don't sign a labor agreement.

Because our country has rejected the public service modal which sees public service as an ordinary labor operation and we are distinct from Anglo-Saxon or the Common law countries location modal, renewed corporative modal which is included in it or a system where the officials get into a labor relation with the organization based on a contract.
So I think it is appropriate to conceive "labor operating procedure" as "administrative rules" pursued within the agency, to organize officials work from the administration, to define the characteristics of legal standards determining ritual order to improve their performance.

A type of legal standard systemization Chronological legal incorporation, classifying and reinstating of legal standards by systematic incorporation on police organizations have been done regularly. The most of the total 16 compilation works are by passed subject used legal act type or legal standard act classifying systemized incorporation and the rest 6 has classified the operations and used integrated incorporation method.

Any case of police organization and legislations regarding the officer operations using these two systemization techniques has been compiled by the sequence of Government decision, minister and ministry decision, decision by the Head of the National police agency, subsidiary organization and decision by the head of a division.

It can be seen that no codification of internal legal acts regulating the police organization operations have been done. But Standard operating procedure (National police agency of Mongolia, 2011, 2012, 2013) made in 2011 has a legal standard act systemization codification, stable serving characteristics according to the content of the rules, procedure and instructions approved the head of the Police central organization and is a new act compilation work which is compiled and integrated. (See Figure №1)

As for the research population the police organization has over 10000 rural and urban officials and we merged the 3046-competent result on SPSS program from the received 5000 questionnaires. 
Figure №1. Classification of Police Standard Operating Procedure

\begin{tabular}{|l|l|l|}
\hline Category & Topic & Number of rules \\
\hline Chapter one & Police administration, organization & 35 \\
\hline Chapter two & Common activities of the officers & 48 \\
\hline Chapter three & Crime detection, investigation & 26 \\
\hline Chapter four & Maintain public order & 22 \\
\hline Chapter five & Internal troops activity & 4 \\
\hline Chapter six & Administrative activities of Police organization & 32 \\
\hline Chapter seven & Information and statistic activity & 14 \\
\hline Chapter eight & Finance, logistic activity & 15 \\
\hline Chapter nine & Human resource and military service communication & 48 \\
\hline Нийт & 9 chapters & 243 \\
\hline
\end{tabular}

$13.9 \%$ of the officials participated in the research were $18-25,29.8 \%$ were $26-30$, $19.7 \%$ were $31-35$ and the $63.4 \%$ are up to 35 years old. While the $12 \%$ of the total police personnel are female, the $88.2 \%$ of the officials who have participated in the research were male and the $11.8 \%$ were female, which shows the appropriate level and positive influence on the reality of the research work.

In this regard, this is likely that there is not sufficient research, inadequate training in legal schools and less emphasis on the significance of the codification of legislation. When the codification emerged by the beginning of the $\mathrm{XX}$ century through different legal systems, some developing countries were resistant of accepting and reluctant of codification. Consequently, those factors could be impacted on insufficiency in research and legal techniques issues within the concepts of legal theories in some countries.

Therefore, it is necessary to establish the concept of organizational internal guidelines and rules should be regulated as the administration procedural acts. There are also some instances of transparently regulating rules to draft internal and external administration procedural acts.

According to the survey to reveal the potentiality and power of codification procedural acts and norms of police, $21.5 \%$ - accepted as fully potential and powerful to enforce, 55.2\%- in some circumstances are enforceable, $20.3 \%$ inadequately regulated, $3.0 \%$ - totally unacceptable to enforce and means 1.95 transferring them to 0-3 scale, but 3.25 averaged in $0-5$ scale. The survey result reveals the importance of strengthens in qualification of codification that has already began processing.

There are some legal techniques to establish organizational procedural normative. In Germany, for instance, package documents and research Schubert's circle and Hoshin Kanri model, and create X matrix to enhance procedural norms and eliminate legal loopholes.

Additionally, regarding the survey of police procedural normative and standards, 20 percent of the survey participants evaluated that it was inadequately defined, unclear, impractical to enforce. $80 \%$ - fully accepted as normative to enforce. Since the approval of the Law on Administrative in 2015, there have been ongoing measures to codify norms and guidelines as well as update the registration them within our country.

Hence, once the organizational internal administrative guidelines and norms are directed externally could be illegal procedure. Besides that, there have been measures to improve regulations of police procedural norms and with consistent the reform of police laws. Meanwhile, it is worth emphasizing that the administrative procedural codification should be kept in legal reform process through 
improving the previous impractical issues.

One of the significance of the codification of legal acts its easiness in usage and application are revealed through another survey with 11 open questions that emphasizing its practical usage $-22.2 \%$, easy to find- $16.8 \%$, established credibility to enforce normative- $13.4 \%$. Some scientists and scholars emphasized that the significance of understanding the codification of normative and codes needs to be broadened, furthermore, it would be more effective in legal technique to pursue in enforcement.

In regard to the improvement of codification of police standards operating procedure, and normative, 147 feedbacks were received from the various police personnel and $48.9 \%$ suggesting to improve, $28.5 \%$ organizing training in enforcement, $8.8 \%$ needs some amendments to guarantee legal status of staff, $4.7 \%$ has not any suggestion in improvement. As above survey illustrates that any particular challenges in this respect of codification of police standards operating procedure and emphasizing the value of organizing training and qualification in enforcement.

The research evaluation is conducted by using the following variables; independent variable $(\mathrm{Y})$ - codified police procedures and normative; dependent variable (X)- impact of the outcome;

$\mathrm{X} 1=4.09-$ the expectation and needs of the police personnel to codify police procedure

$\mathrm{X} 2=3.55$ - knowledge of systemization and codification of police procedure

$\mathrm{X} 3=3.65$ - practical application

$\mathrm{X} 4=4.36$ - training/share knowledge of systemization and codification of police procedure

X5=4.0- access of systemization and codification of police procedure

X6=3.25-implementation of systemization and codification of police procedure

Formula and estimation of the research:

$$
Y(x)=\frac{x_{1}+x_{2}+x_{3}+x_{4}+x_{5}+x_{6}}{6}=\frac{4.09+3.55+3.65+4.36+4.0+3.25}{6}=3.82
$$

It is estimated in the research that each 6 dependent variables are evaluated by means of 3.82. Moreover, the research outcome is resulted as $76.3 \%$ through systemization and codification of police standards operating procedure which means of entire effectiveness illustration.

Furthermore, it is worth noting that the research methodology should be revised for more effective outcome measurement. $23.7 \%$ (rest of 100\%) is the estimated as the negative (unsatisfied application) results of the survey that illustrating needs of improvement in codification of police procedure.

\section{CONCLUSION}

The following conclusions are presented the police standard and operating procedural codification in regard to legal theoretical and practical issues, including administrative law,
According to the criminal justice theory, professionals and practitioners in legal justice system are necessary to have knowledge and qualifications to codify the normative, guidelines and standards, moreover, to apply and enforce them in practice. Otherwise, it is supposed to step behind in development of legal education.

This is also unrealistic to evaluate the implementation and enforcement of all 243 police procedural normative simultaneously however, it should be reviewed each operating procedural standards and separately and create an assessment criterion respectively.

labor law, legal technique, legal codification, interconnectedness in quality management.

First, this is necessary to create and establish the fundamentals of administrative procedural 
technological rules which are consisting of legal elements that are enforceable to practice in accordance with of rule of law;

Second, it is necessary to understand the codification of police procedural normative and code which is researched in this thesis and systemized act as the internal administrative procedural act within legal procedural theory.

Third, it is worth emphasizing the research objective as the internal administrative acts that needs to be systemized and developed properly, on the basis of the previous researches on legal theory and philosophy, administrative law, police administrative law as well as researchers, scholars, from both international and domestic;

Fourth, the research is emphasizing that codification of police procedural normative is the main fundamentals of organizational professional standards and management.

Eventually, the research suggests the amendments the Law on Legal Status of Government agency of Mongolia which regulates the administrative operating procedure, particularly, provision of 10.3 , and 10.4 of article 10 defined as "internal labor procedural rule" to the "internal administrative procedural rule" for the more effectiveness of legislation. 


\section{REFERENCES}

1. Jamyan B. On some issues of classifying and organizing acts of establishing norms of authority in People's Republic of Mongolia. Ub.: Legal commission of Mongolian Government., 1967.

2. $\quad$ Amarkhuи O. Law theory's 15 lectures. Ub., 2008. p.59-61.

3. Lundeejantsan D. Making law and legal techniques. Ub. 2016. p.116-132.

4. Charles R.Swanson. Leonerd Territo and Robert W.Taylor. Police Administration: structures, process, and behavior, 8th edition. Prentice Hall., 2011. p.174.

5. P.J. Ortmeier and Joseph J. Davis. Police Administration: A Leadership Approach. US., Administration of Justice Grossmont College. 2010.

6. Barry Moule and Lina Giavara., Policies, procedures and standards: an approach for implementation, Information Management and Computer Security, Vol 3 Iss.

7. Nick Kapp. Developing SOP. Professor of Skyline College, San Bruna. Ca. US. from http: skylinecollege.edu/

8. Dwayne Orrick W. Developing a Police Department Policy-Procedure Manual. Department of Justice U.S. International Association of Chief of Police. 2008. p.2

9. Jeannette L. Nolen., Standard operating procedure (SOP), 12-29-2009

10. Nyamsuren Ch. General legal theory. 2nd Edition. Ub., 2017. p.254

11. Alekseev V.V. Government and law. Ub., 2004. p.124.

12. Lazarev V.V. General theory of right and government. M., 1997. Page 129

13. Nyamsuren, Ch (2017). General legal theory. ( $p$ 254). Ulaanbaatar city, 2nd edition.

14. Kashanina T.V. Legal technique, 2nd Edition. Ub., 2016, p. 236.

15. Nancy J. Campbell., Writing Effective Policies and Procedures: A step-by-step Resource for Clear Communication, US, Library of Congress Cataloging-in-Publication Data, 1997.

16. David N. Muchemu., How to write standard operating procedures and work instructions: $A$ handbook for quality managers and quality engineers, Second edition, CGMP University, 2012, US, p43.

17. Isin Akyar. Acibadem University of Turkey. "Latest Research into Quality Control" Chapter 17 Standard Operating Procedures (What are they good for?). 2012. pp.367391. from http://dx.doi.org/

18. Harold J. Krent. Standards of Review: Nonstatutory legal issues., Chicago-Kent College of Law, 2001

19. Andrew H. Baida. A Response to "Accardi Comes to Maryland", 2014., from http:// www.msba.org/. Rodney A. Smolla "The Erosion of the Principle that the Government Must Follow Self-Imposed Rules", from http://ir.lawnet.fordham.edu/

20. Daniel Carpenter., Professor of Government, Harvard University, A Summary of Theoretical Perspectives - Weberian, Behavioral, Contractual, Cultural, 2010, from http://people.hmdc.harvard.edu/

21. Kashanina T.V. Legal technique, 2nd Edition. Ub., 2016, p.236.

22. Kelsen, Hans (1960) [1934]. Pure Theory of Law. Translated by Knight. Berkeley, CA: University of California Press.

23. Hart H.L.A. The Concept of Law. Oxford., 1961. p.77.

24. Pylipenko A.I. Classification and systemization of law in France. //Russian true. 2001. №9

25. Kabrik, P (2007) Codification (p 108)

26. Reinhard Zimmermann., Codification: The Civilian Experience Reconsidered on the Eve of a Common European Sales Law, 2014, Codification in International Perspective, p.13

27. Baasan L. Labour law of Mongolia. 2nd Edition. UB., 2000; Labour law of Mongolia. 3rd Edition. Ub.:Otgontenger University., 2010; 